IMMEDIATE IMPACTS OF HURRICANE IKE ON THE TEXAS COAST

\author{
Billy L. Edge ${ }^{1}$, Lesley Ewing ${ }^{2}$, Robert G. Dean ${ }^{3}$, James M. Kaihatu ${ }^{4}$, Margery Overton ${ }^{5}$, Spencer M. Rogers ${ }^{6}$, \\ Paul A. Work ${ }^{7}$
}

\begin{abstract}
Hurricane Ike was a large storm as it crossed the Gulf of Mexico. When it entered into Texas it caused a storm surge of up to $4 \mathrm{~m}$ and substantial waves with high winds represented by a Category 2 hurricane. The storm caused extensive flooding and erosion which led to significant property damage on Boliver Peninsula and on Galveston Island. COPRI (Coasts, Oceans, Ports and Rivers Institute) of the ASCE (American Society of Civil Engineers) sponsored a team of engineers and scientists to observe the coast and collect perishable data approximately one month after the storm. One of the main conclusions from the inspection of buildings was that elevation was a key determinant for survival. Members of the team returned for another visit approximately one year later to observe how the recovery had progressed. Those observations show some redevelopment but also some serious flaws in the coastal management implementation.
\end{abstract}

Keywords: hurricanes; Hurricane Ike; damages; coastal management; resilience; storm surge

\title{
INTRODUCTION
}

Hurricane Ike made landfall on the Texas coast at 2:10 a.m. on September 13, 2008, as a Category 2 hurricane. The eye of the hurricane crossed over the eastern end of Galveston Island and a large region of the Texas and Louisiana coast experienced extreme winds, waves and water levels. The storm created large impacts from overtopping, overwash, wind and wave forces and flooding. Major damage ranged from Freeport, Texas, to the southwest, to Port Arthur, Texas, to the northeast. The objective of this paper is to describe the storm impacts and identify lessons learned.

Through the support of the Coasts, Oceans, Ports and Rivers Institute (COPRI) of the American Society of Civil Engineers (ASCE) a team of 14 coastal scientists and engineers inspected the upper Texas coast in early October 2008. The objective of the field survey was to collect perishable information from the effects of the storm. From the observed effects of the storm, lessons learned were developed indicating what survived and what modified design practices would be needed for those structures that failed. The COPRI team surveyed Hurricane Ike's effects on coastal landforms, structures, marinas, shore protection systems, and other infrastructure. Damages ranged from very minor to complete destruction, depending upon location and elevation. Bolivar Peninsula, to the right of the hurricane path, experienced severe damage and three peninsula communities were completely destroyed.

Fishing piers had much damage and a few large fitted stone were removed from the groins fronting the seawall on Galveston Island. The famous Galveston seawall performed well except where the backfill was lost and flanking occurred. The most severe damage was the western end of the seawall, a location that was badly eroded due to flanking. Beach erosion and prominent overwash fans were observed throughout much of the area investigated and are clear in the aerial photographs immediately after the storm and were observed on the ground.

One of the main conclusions from the inspection of buildings was that elevation was a key determinant for survival. This was often evident in buildings where floor joists were below the wave crests leading to extensive damage or destruction. The degree of protection provided by geotextile tubes also varied with elevation. The Galveston Seawall was high enough to provide protection from much of the storm surge, although there was some overtopping and debris was washed over Seawall Boulevard. In contrast, the geotextile tubes that were used on Bolivar Peninsula and west Galveston were too low to provide an effective barrier to extreme storm surge or to prevent overtopping. Scour and wave erosion were noticeable for all structures, removing sand from the jetties at Rollover Pass, eroding backfill from the west end of the Galveston Seawall and dislocating toe stone and causing rotation of many geotextile tubes.

\footnotetext{
${ }^{1}$ North Carolina State University (bledge@ncsu.edu)

${ }^{2}$ California Coastal Commission (lewing@coastal.ca.gov)

${ }^{3}$ Univ. of Florida (dean@coastal.ufl.edu)

${ }^{4}$ Texas A\&M University (jkaihatu@civil.tamu.edu)

${ }^{5}$ North Carolina State University (overton@ncsu.edu)

${ }^{6}$ North Carolina Sea Grant (rogerssp@uncw.edu)

${ }^{7}$ Georgia Institute of Technology (paul.work@gtsav.gatech.edu) 


\section{THE LOCATION}

Galveston Island and Bolivar Peninsula are low lying barriers that are typical on the northeast coast of Texas facing the Gulf of Mexico. Much of Bolivar is below $2 \mathrm{~m}$ above mean sea level (MSL) and some areas are as little as one meter above MSL. In general, these barriers are sand starved and some areas are highly erosional. Beach nourishment has been used in part to address this problem on Galveston Island. A small nourishment project (Spadoni, 1996) of 542,000 $\mathrm{m}^{3}$ was completed in 1995 and several placements of about 53,000 $\mathrm{m}^{3}$ occurred between 1998 and 2000 (Ravens and Sitanggang, 2002) on Galveston Island.

Behind these barriers is the Galveston Bay system, including several smaller bays that extend to Houston as shown in

Figure 1. There is very little shoreline and flooding protection around the interior of Galveston Bay. Figure 1 also illustrates the track of Hurricane Ike as it approached and crossed the Galveston Island and continued over the Bay to Houston and Baytown, Texas.

Following the 1900 hurricane that devastated Galveston, killing more than 8000 people, a seawall was built to protect the city (Hansen, 2007). The seawall was completed in 1952 and extends nearly 20 $\mathrm{km}$ from the Houston-Galveston Entrance Channel.

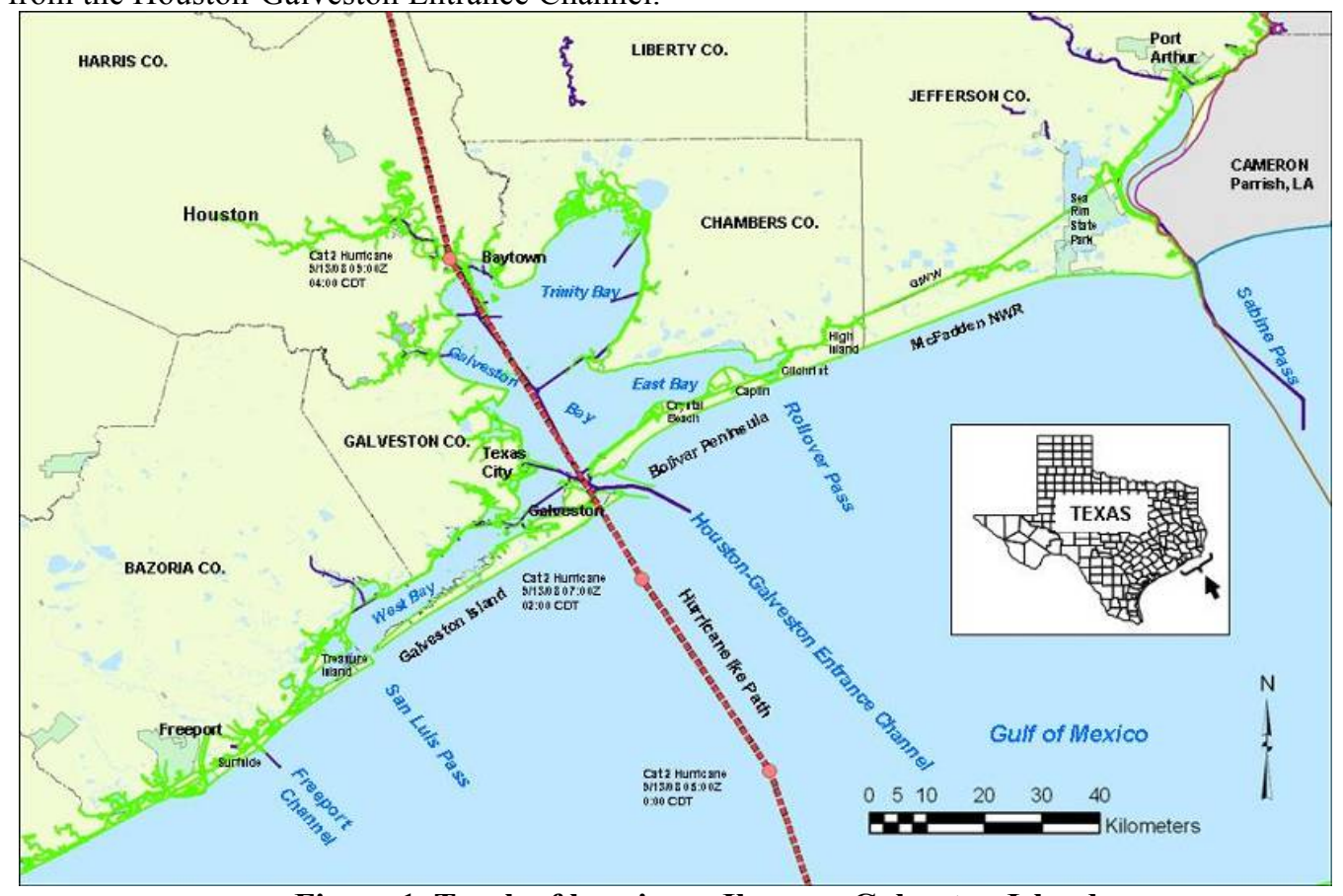

Figure 1 Track of hurricane Ike over Galveston Island

Other than the seawall, the only protection provided to the barriers is a line of geotextile tubes facing the Gulf coast. The geotextiles cover a very large part of the coastline of Bolivar and several kilometers on Galveston Island, west of the seawall. The seawall was clearly designed for hurricane protection, but the geotextile tubes were not represented as hurricane defense.

\section{HURRICANE IKE}

Figure 2 shows the track of Hurricane Ike as it formed from a tropical wave off the coast of West Africa on August 28, 2008. It became a tropical depression on September 1 in the Atlantic basin and moved west northwest over the tropical Atlantic Ocean and rapidly intensified to a tropical storm. By September 3, Ike was a Category 1 hurricane and it quickly grew to a Category 4 storm with peak winds of $65 \mathrm{~m} / \mathrm{s}(126 \mathrm{kts})$. Although it weakened to a Category 2 on the $5^{\text {th }}$ and $6^{\text {th }}$, it regained strength to a Category 4 storm on the $7^{\text {th }}$. After it passed over Cuba it lost and then regained strength until it was a Category 2 hurricane and continued northwestward through the Gulf of Mexico. Ike made its U.S. landfall over the northeastern end of Galveston Island about 2:10 a.m. CDT on September 13, maintaining its strength as a Category 2 storm. The National Hurricane Center (NOAA) reported maximum sustained winds at $49 \mathrm{~m} / \mathrm{s}$. Ike did not begin to weaken until it moved inland after traversing Galveston Bay at which time it quickly downgraded to a tropical storm. At landfall the storm was moving to the northwest at $8.6 \mathrm{kts}$, and the sustained wind speed of $49 \mathrm{~m} / \mathrm{s}$, made Ike a strong Category 
2 storm (National Hurricane Center archived reports). Ike had hurricane strength winds extending up to $190 \mathrm{~km}$ from the center of the storm, with tropical storm force winds to $440 \mathrm{~km}$ as shown in Figure 3.

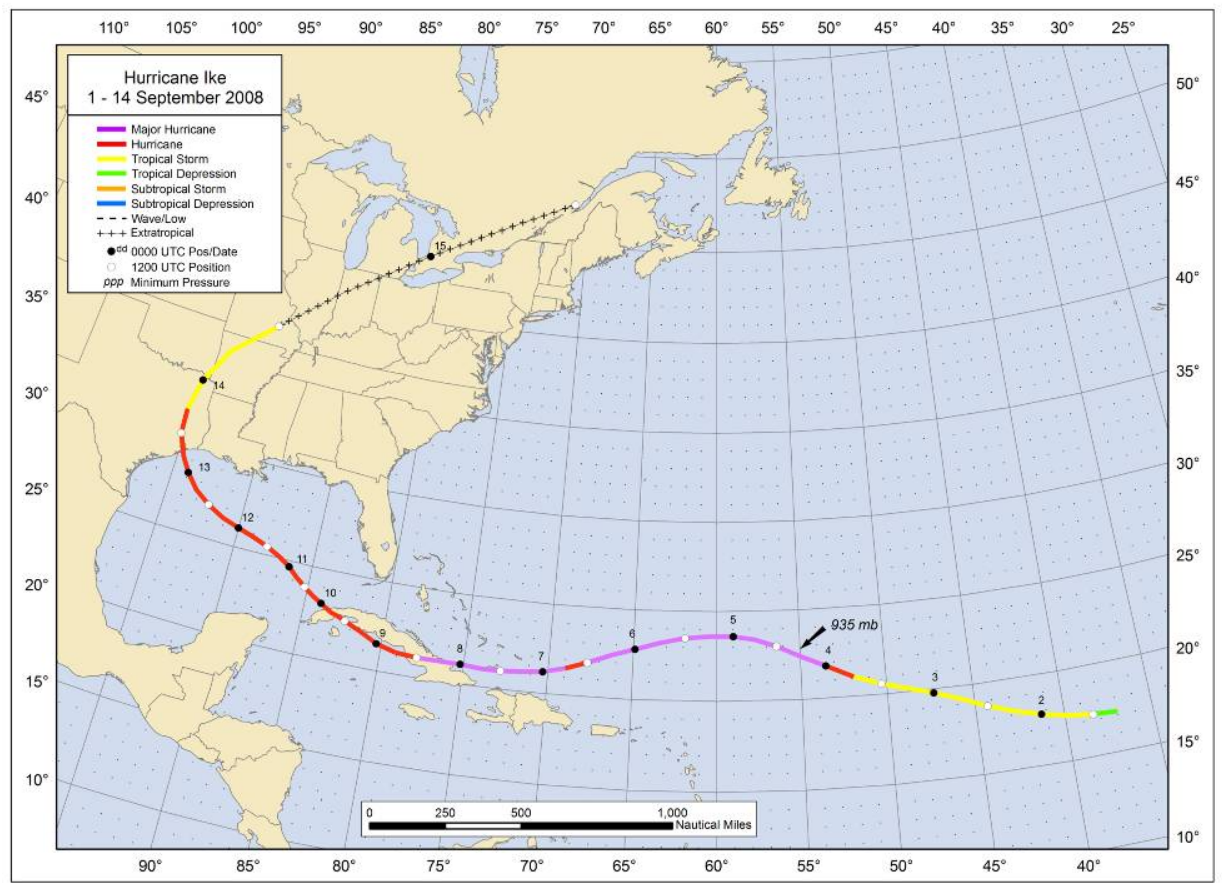

Figure 2 Best track positions for Hurricane Ike, September 1-14, 2008. Source: Berg (2008)

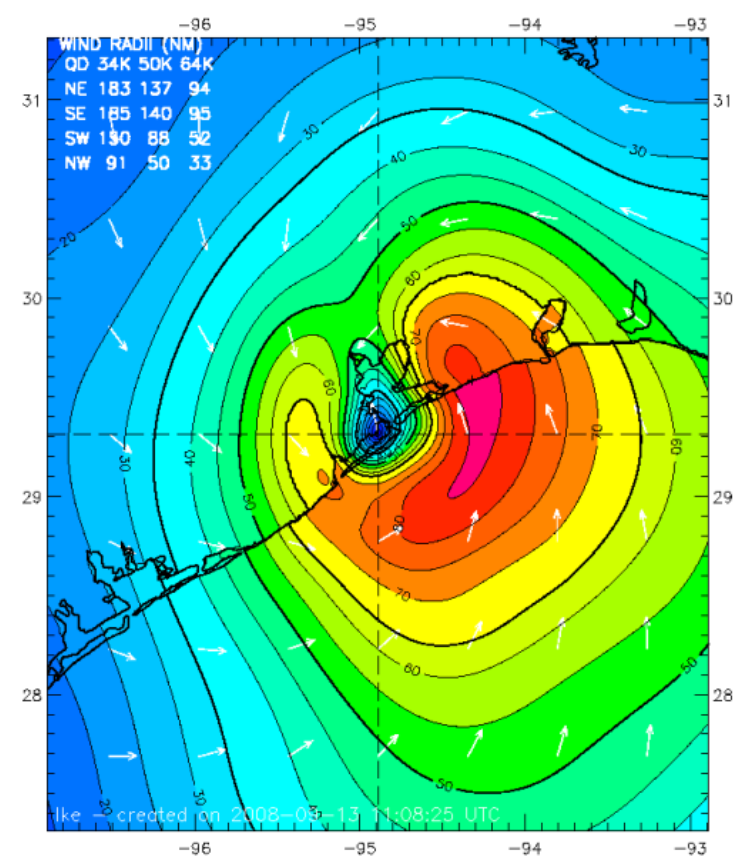

Figure 3 Wind field at 7:30 a.m. on September 13, 2008, as Hurricane Ike made landfall near Galveston. (Wind speed is in knots) Source: NOAA Hurricane Research Division

\section{Water Levels}

NOAA maintains several stations for measurement of winds and water levels in the area and immediately before the storm the USGS placed numerous storm gages throughout the coastal area as shown in Figure 4. Several of the NOAA water-level sensors failed as water levels increased during the storm; thus, the peak storm surge was not recorded everywhere. However, in many cases, backup 
systems recorded data throughout the storm. Figure 5 presents the storm surge anomalies recorded in the general area from NOAA gages. An interpretation of these results is also presented by Kraus and Lin (2009). Results discussed here are based on preliminary data. Subsequent watermark surveys were conducted by FEMA, the state, and others, including members of the ASCE site visit team. These surveys will increase knowledge of the water levels during the storm.

Immediately before landfall, Prof. Andrew Kennedy (2010) of Notre Dame University deployed nine gauges, which recorded surges and waves offshore at locations shown in Figure 4. Eight of these gauges were recovered and provided excellent data.

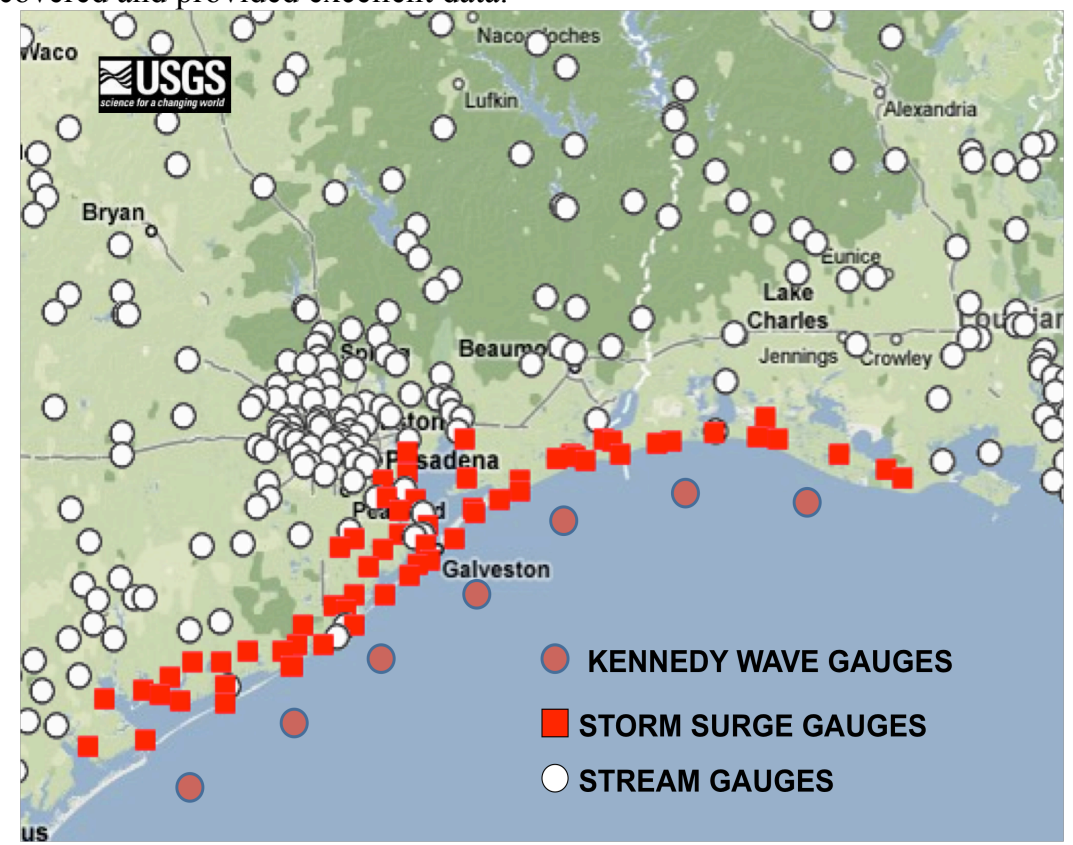

Figure 4. Location of storm surges and wave gages

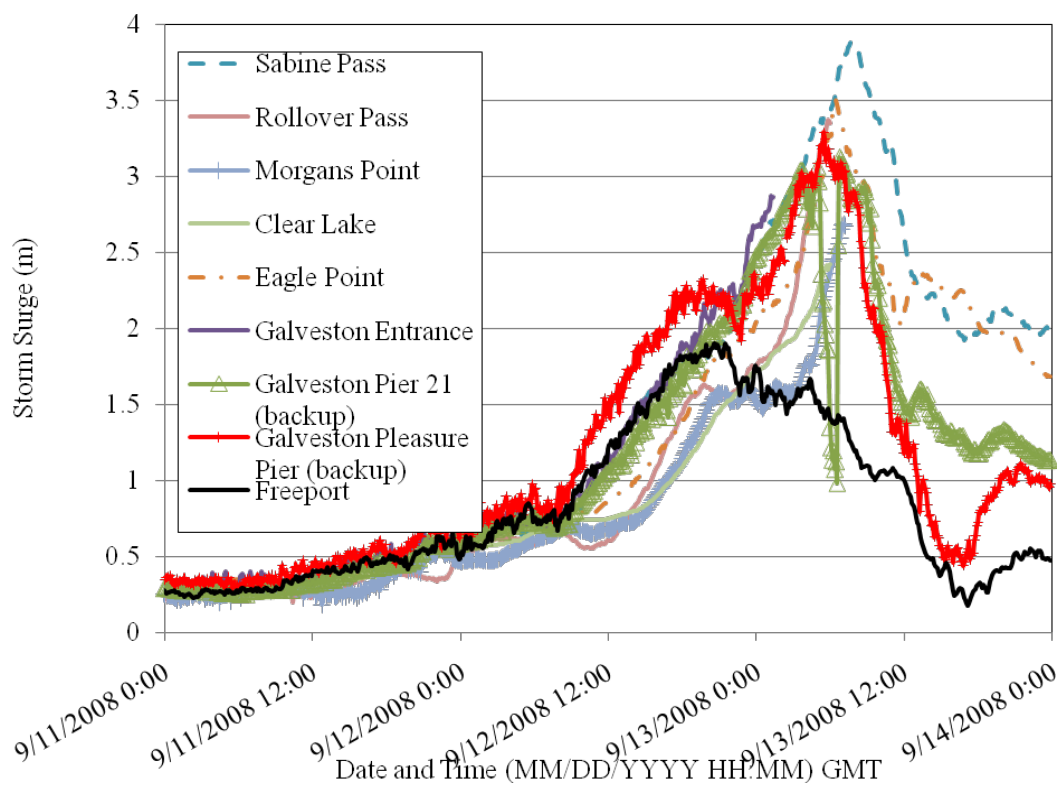

Figure 5 Storm surge hydrographs recorded at NOAA stations near Galveston with tides and waves removed.

Figure 6 compares the water levels from the Kennedy gauges installed in approximately $9 \mathrm{~m}$ depth near Galveston, Bolivar Peninsula, and Rollover Pass with tide gauges at Galveston Pier, Rollover Pass, and Sabine Pass. The black lines in the figures represent the Kennedy gauge results. For the results presented, the peak storm surge occurs at Sabine Pass and is approximately $4.6 \mathrm{~m}$ above MSL. Another very interesting observation from this data is the forerunner (Bunpapong et al. 1985) that 
appears in the record, occurring about 6 hours before the main peak of the storm surge. This is also apparent in the NOAA backup gage at Galveston Pleasure Pier as seen in Figure 5.
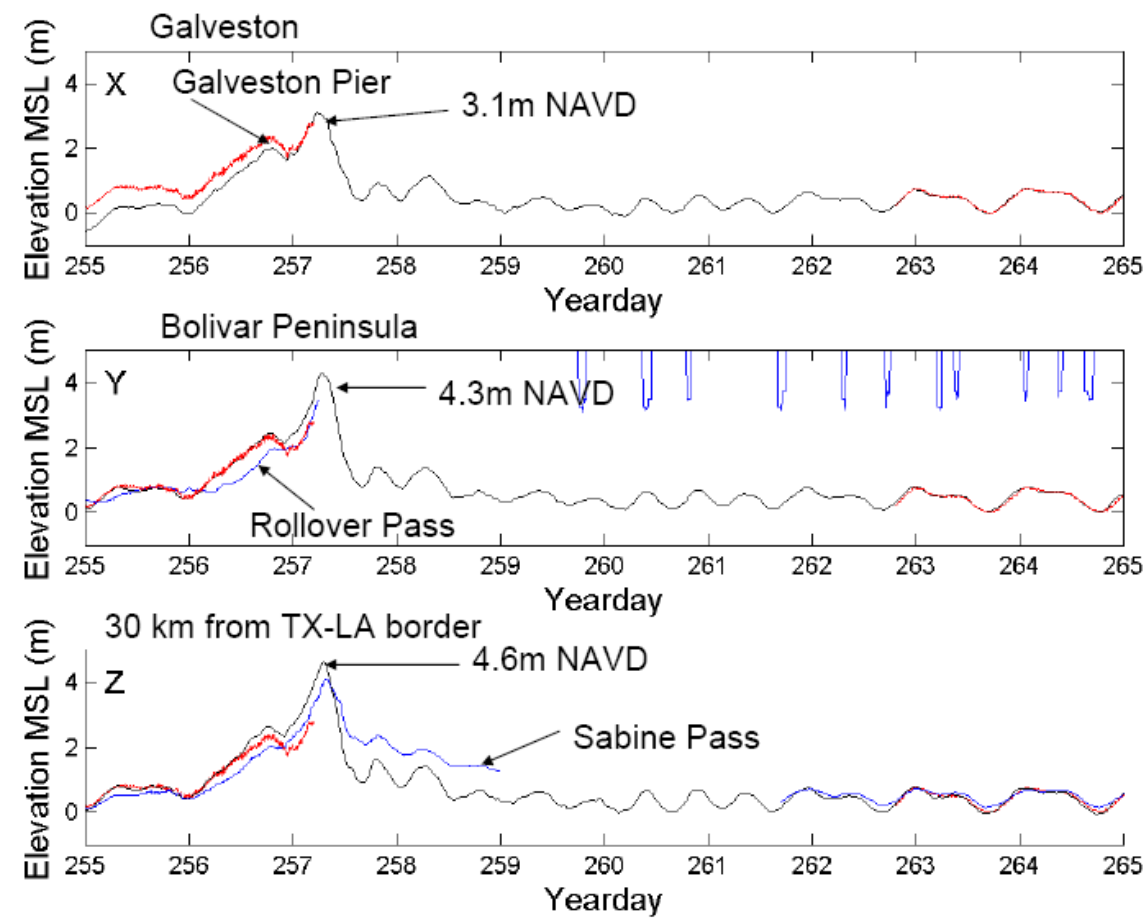

Figure 6 Storm surge results based on gauges installed by Kennedy (2010) compared to tide gauge results at Galveston Pier, Rollover Pass, and Sabine Pass

\section{Waves}

Figure7 presents measurements of significant wave heights from all eight gauges that provided data along the Texas Coast. Also included are (1) the measured wave heights from NDBC Buoy 42035 that broke its mooring and drifted during the storm and (2) the significant wave heights if the waves were in local equilibrium with the winds at the time. The time axis is relative to "Landfall Day." It is very interesting to observe that the peak waves occurred from six to 18 hours before landfall. It is very clear that the largest waves were in the region of High Island or the upper end of Bolivar Peninsula.

\section{SHORELINE CHANGES}

Aerial photography was available from the Texas General Land Office to represent pre-storm conditions. The 2006 TGLO shoreline was digitized from the photographs in ArcMap using the visible high-water line. Post-storm information was obtained from the aerials collected by NOAA and its National Ocean Service (NOS) and National Geodetic Survey (NGS) Remote Sensing Division on September 15 and 18, 2008 within a few days of the storm landfall. From these aerials a "storm" shoreline was digitized onto these post storm images using the aerial photography at the landward extent of the beach identified as the boundary between the upland (in most locations this was a scarp in the lawns of upland property) and the beach or a post-storm high water line.

These photos showed severe erosion of the beach and near total destruction of upland structures in the Rollover Pass area of Gilchrist that is on Bolivar peninsular. The pre- and post-storm photos in Figure 8 shows that sand had overwashed the entire narrow width of this part of Bolivar Peninsula. Despite the geotextile protection, the beachfront experienced major erosion with the formation of localized erosion channels due largely to the thin veneer of sand in this area. The geotextiles appeared to somewhat reduce, but not prevent, the extent of erosion farther landward compared to unprotected sections and areas where the tubes were damaged. 

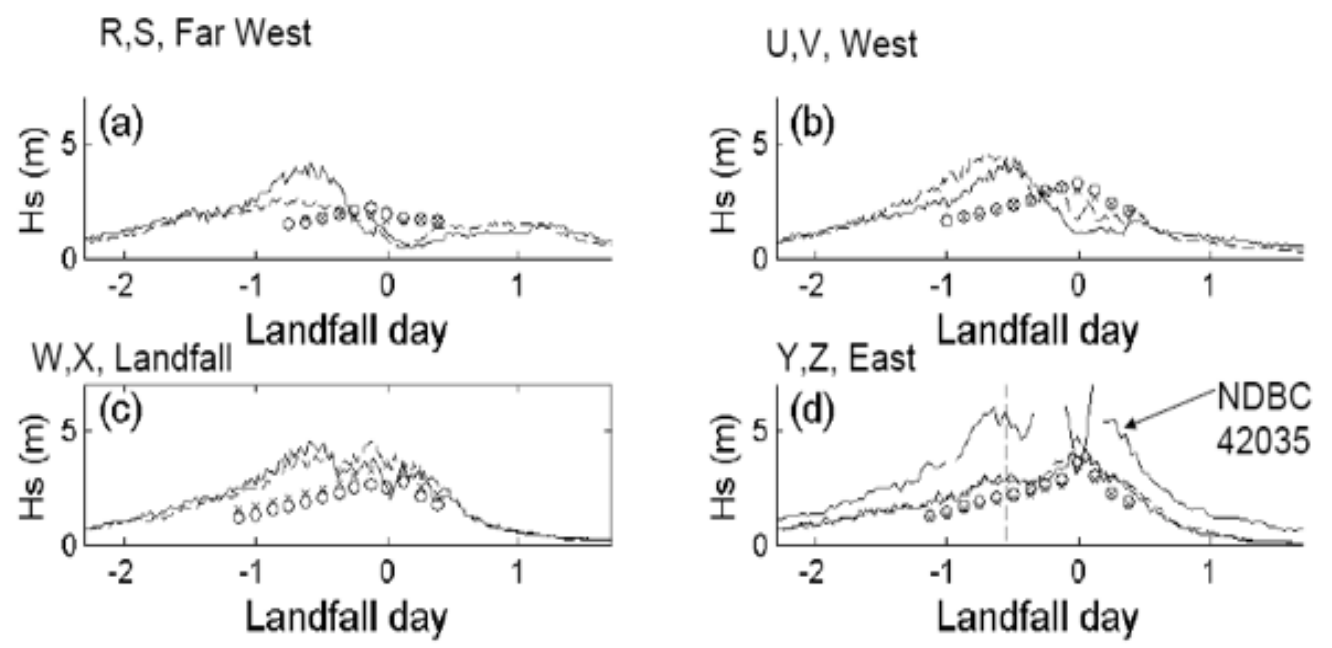

Figure7 Significant wave height at all eight Kennedy gauges that recorded waves during Ike.

On Galveston Island, west of the seawall, the beaches of West Beach are narrow (30- to 50-mwide) with low dunes. This area was equally affected by the storm surge as shown in Figure 9 at Pirates Beach on West Beach. Here the shorelines have steadily moved landward since 1930. In about 2005, a sand-filled geotextile tube was constructed at this location and was buried below a dune feature, which is about $20 \mathrm{~m}$ in front of the first row of homes. In the post storm conditions shown in the lower photograph it is clear that overwash penetration occurred between 100 and $150 \mathrm{~m}$ landward of the 2006 shoreline. The dune was completely eroded, and the geotextile tubes were exposed. The landward extent of the post-storm beach is marked with a line.

\section{STRUCTURAL DAMAGES}

\section{Piers}

Prior to Hurricane Ike, there were 11 piers along the upper Texas Coast from Jefferson County to Surfside. The two active fishing piers on Bolivar Peninsula were completely destroyed by the storm and only the pilings were left. Six piers were located along the seawall in Galveston. The wooden pier at 21 st Street was completely destroyed. Two amusement/restaurant piers at 22nd and 23rd streets built on concrete piers were heavily damaged and completely destroyed, respectively. A fishing pier built on the gulf end of one of the groins at 61 st Street was completely destroyed by the storm. The groin was intact, but the concrete surface was damaged. Most of the debris from these three piers was washed up onto Seawall Boulevard. Two fishing piers in Brazoria County also had heavy damage along with a house on a pier at San Luis Pass. The fishing pier at Treasure Island on the west side of San Luis Pass lost $202 \mathrm{~m}$ of its outer end, and the shore access ramp was destroyed.

Figure 10 shows the concrete fishing pier located near 89th Street in Galveston. The total length was about $340 \mathrm{~m}$ of which only $125 \mathrm{~m}$ remain standing. The two-story building on the pier located near the seawall was heavily damaged, and the first floor was completely lost. These damages were mainly caused by the uplift and horizontal wave forces inside the surf zone. The concrete decking panels were lifted upward by the waves and fell through the girders onto the beach or seafloor. The end of the pier remained because it was located outside the surf zone.

The 25th Street pier (also called the Pleasure Pier or Flagship Hotel Pier) with a total length of about $350 \mathrm{~m}$ was the only pier that remained largely intact despite heavy damage to the hotel after Hurricane Ike (Figure 11). Almost all piles of the $25^{\text {th }}$ Street Pier remained in contrast with those of the 89th Street fishing pier. There are several reasons for the differing damage between the 25th Street (hotel) Pier and fishing pier. The clearance between the sea surface and the horizontal beams of the hotel pier was higher than for the fishing pier. Also there was likely deeper embedment of the piles to support the load of the hotel structure and resist the wave forces. Additionally, the water depth seems 
much shallower than that at the fishing pier, which would have made the wave height smaller than that under the fishing pier.

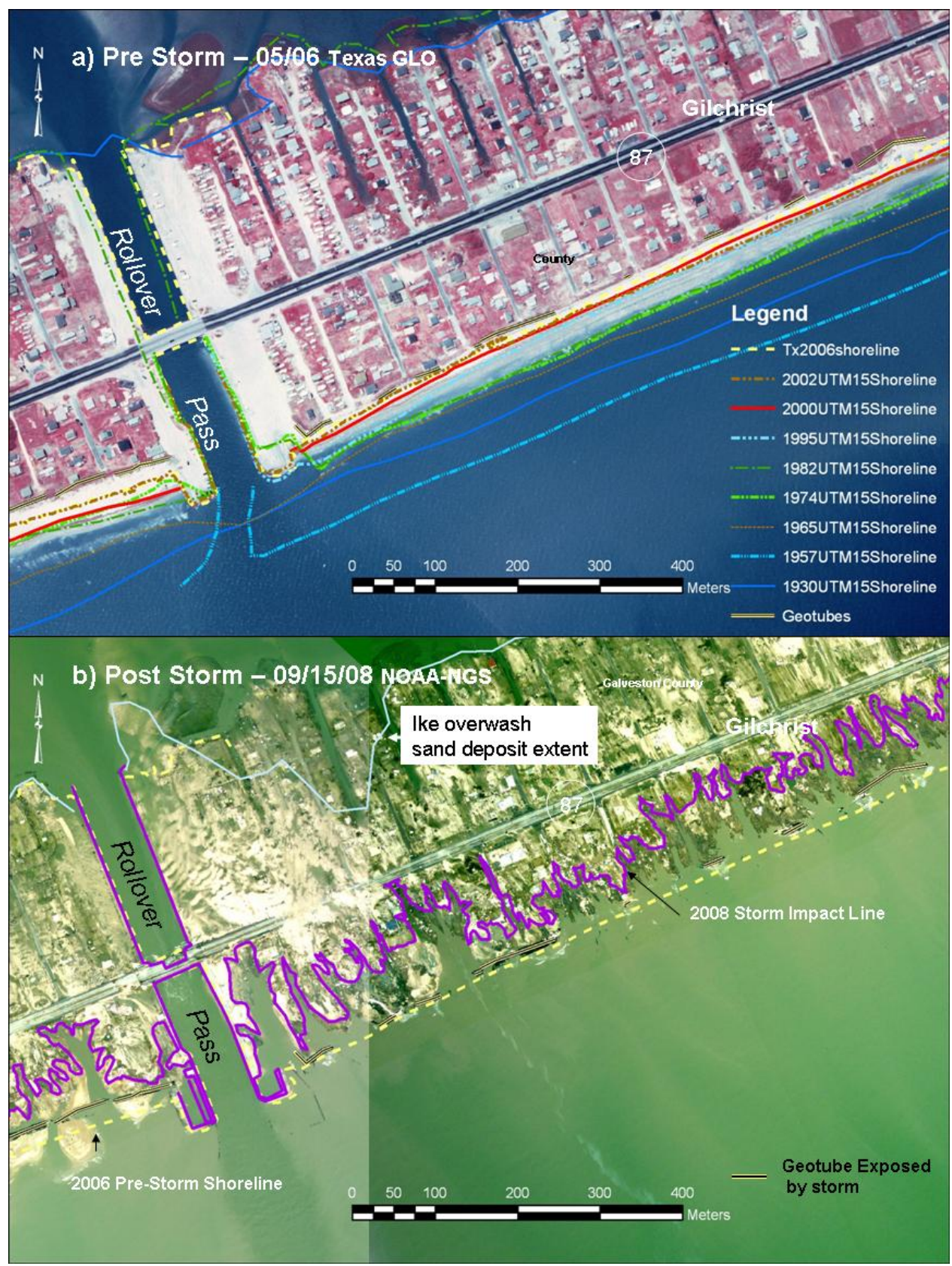

Figure 8 (a) Pre-storm aerial photography of Rollover Pass and Gilchrist with historic shorelines and location of buried geotextile tubes and (b) post-storm impacts of overwash extent and shoreline position 

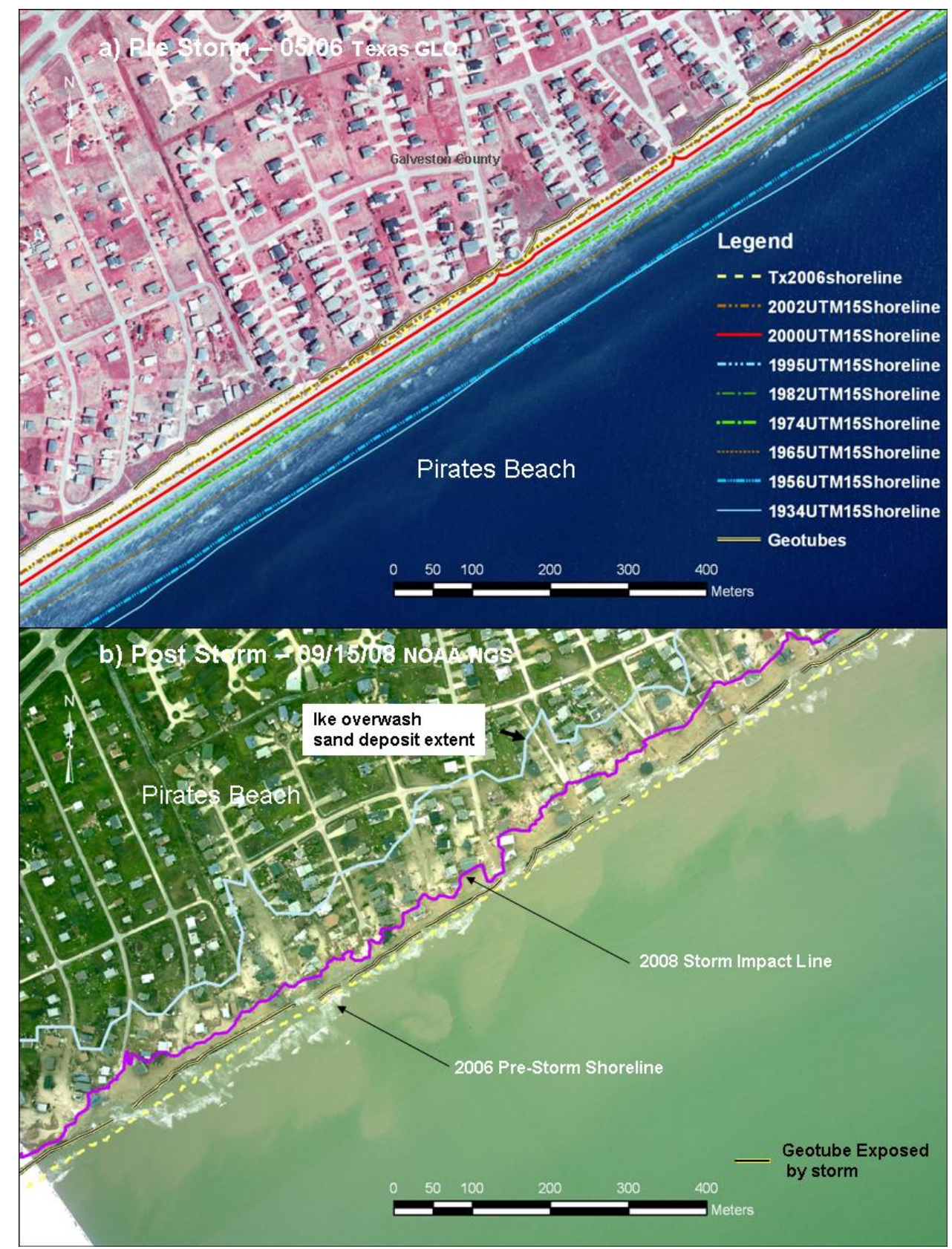

Figure 9 (a) Pre-storm aerial photography of the Pirates Beach area of West Beach showing the historic shorelines and dune over geotextile shore protection and (b) post-storm impacts to geotextile tubes, overwash extent, and shoreline position 


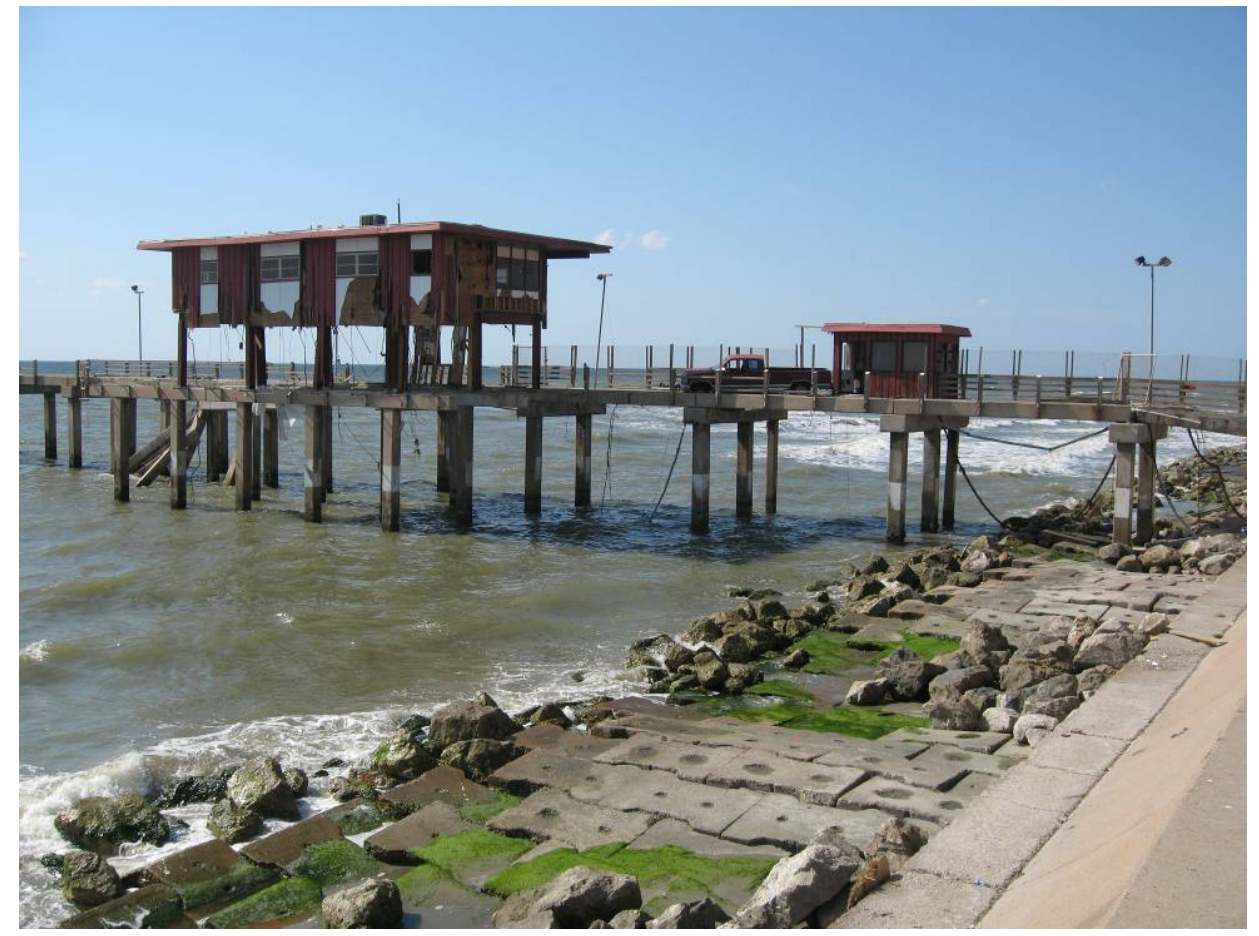

Figure 10 89th Street fishing pier

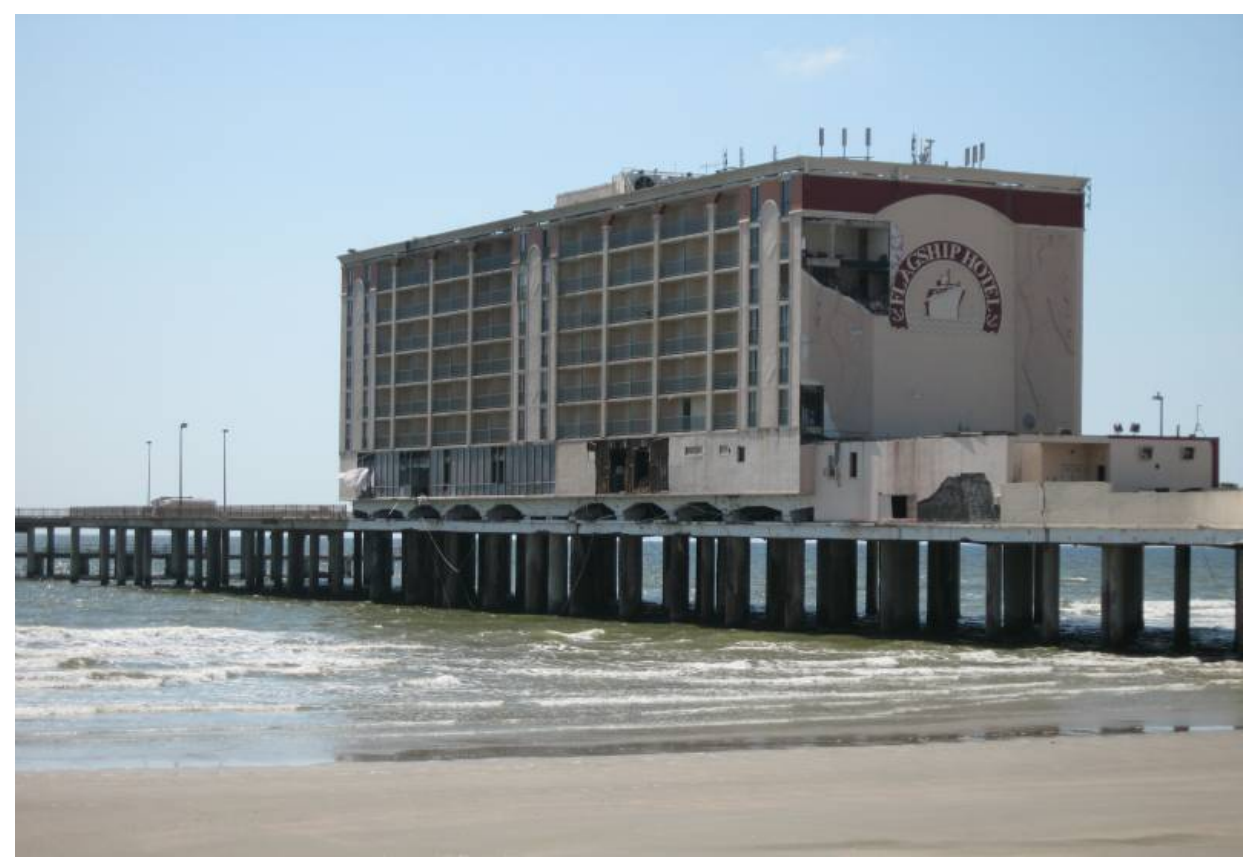

Figure 11 Flagship Hotel Pier

\section{Galveston Seawall}

The Galveston Seawall has been very effective in protecting against storm surge and waves since it was constructed after the 1900 Hurricane. It was effective in preventing erosion of the upland and wave overtopping. Although the highest winds and storm surges were east of Galveston Island, the seawall prevented substantial damage to upland structures. The only substantive damage to the seawall itself occurred at the western end where the seawall was flanked and erosion occurred behind the seawall (Figure 12). Minor damage to the seawall occurred from the loss of backfill in some locations causing a failure of the sidewalk (Figure 13). Although the Galveston Seawall apparently performed well during Hurricane Ike, several observations suggest that the seawall might only be marginally stabile during a future major hurricane. Observations during the field investigation suggest that the 
water level in the backfill behind the wall may have been at a high level, perhaps near the surface, while the water level seaward of the wall was much lower. Elevation of the water level behind the seawall is indicated by failure of numerous locations where an apparent "piping" failure occurred. The piping failure would have occurred if the hydrostatic water head behind the wall caused migration (piping) of the sand backfill through joints in the wall or along utility trenches or similar pathways causing loss of backfill.

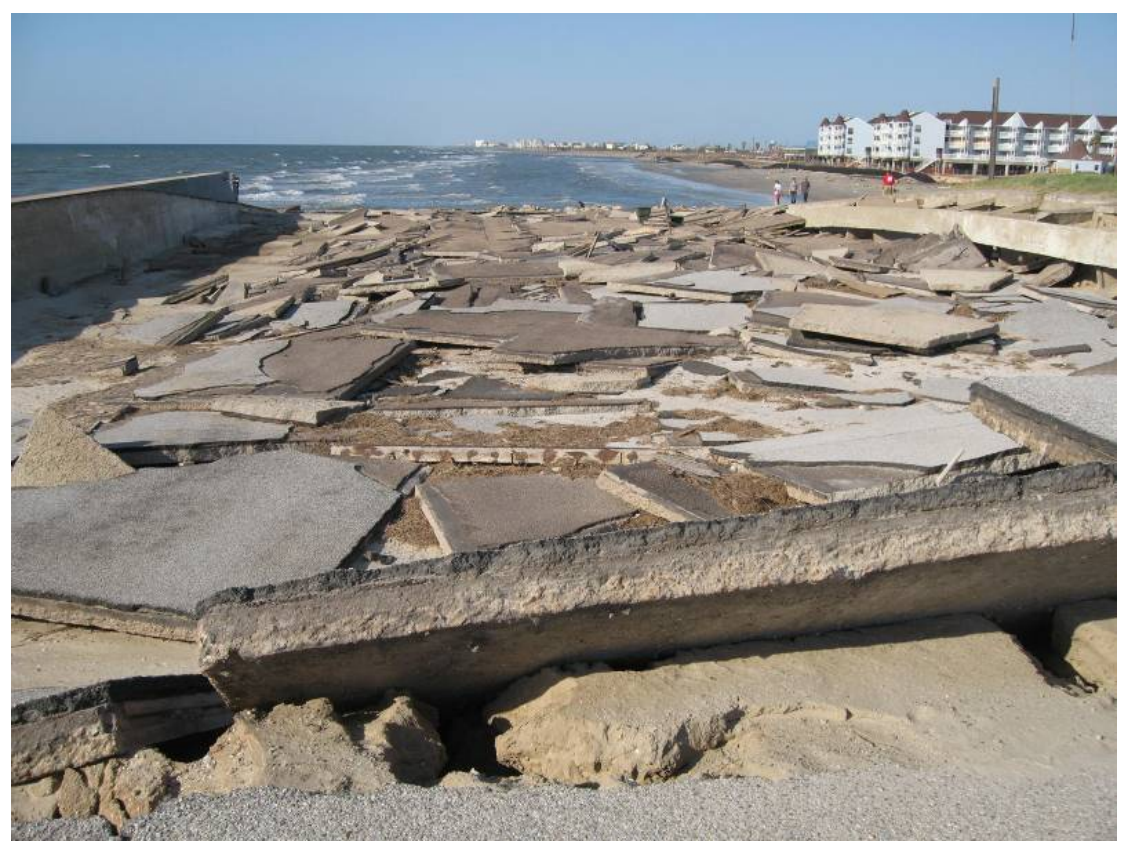

Figure 12 Damage at southwest end of seawall

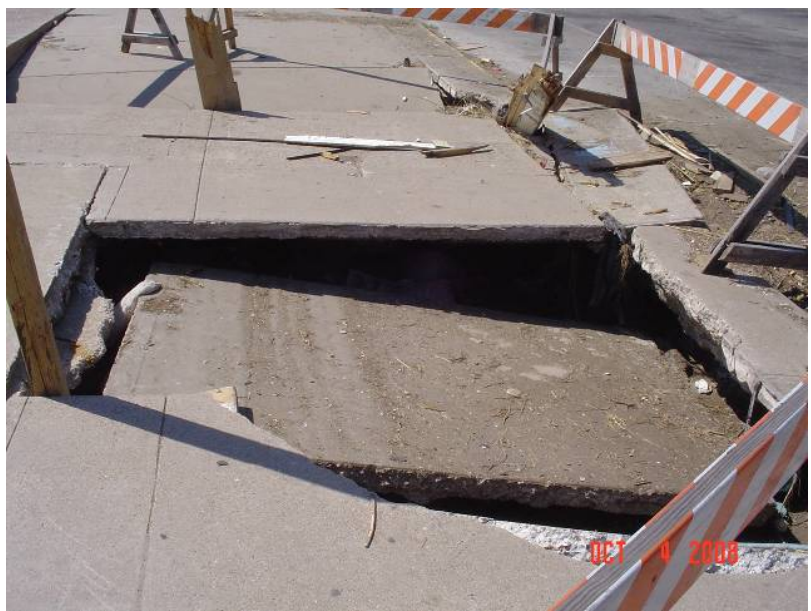

Figure 13 Settlement of slabs behind the seawall caused by piping failures

\section{Groins and Jetties}

There are 15 groins perpendicular to the Galveston Seawall. Nearly all of these groins were constructed from cut stone. Most of the groins had minimal damage. Four of them had a concrete cap to allow walking access on the groin. The concrete surfaces were damaged and some of the rocks were displaced at the gulfward end or along the water line. On the groins with cut stone, some of the stones were dislodged as shown in Figure 14. These stones were picked up by the waves and were displaced to lower levels, leaving a void in the crest and slope of the groin. The stone appeared to be 3 to 5 ton granite.

The jetties at Galveston Bay appeared to be unaffected by the hurricane. The storm surge was high enough to submerge the jetty stones so they were less impacted by the wave conditions. The accretion on the leeward side of the East and West jetties did have an effect on the waves reaching the jetties. 
Similarly, the jetties at Freeport did not have any damages but there was some flanking observed on the East jetty.

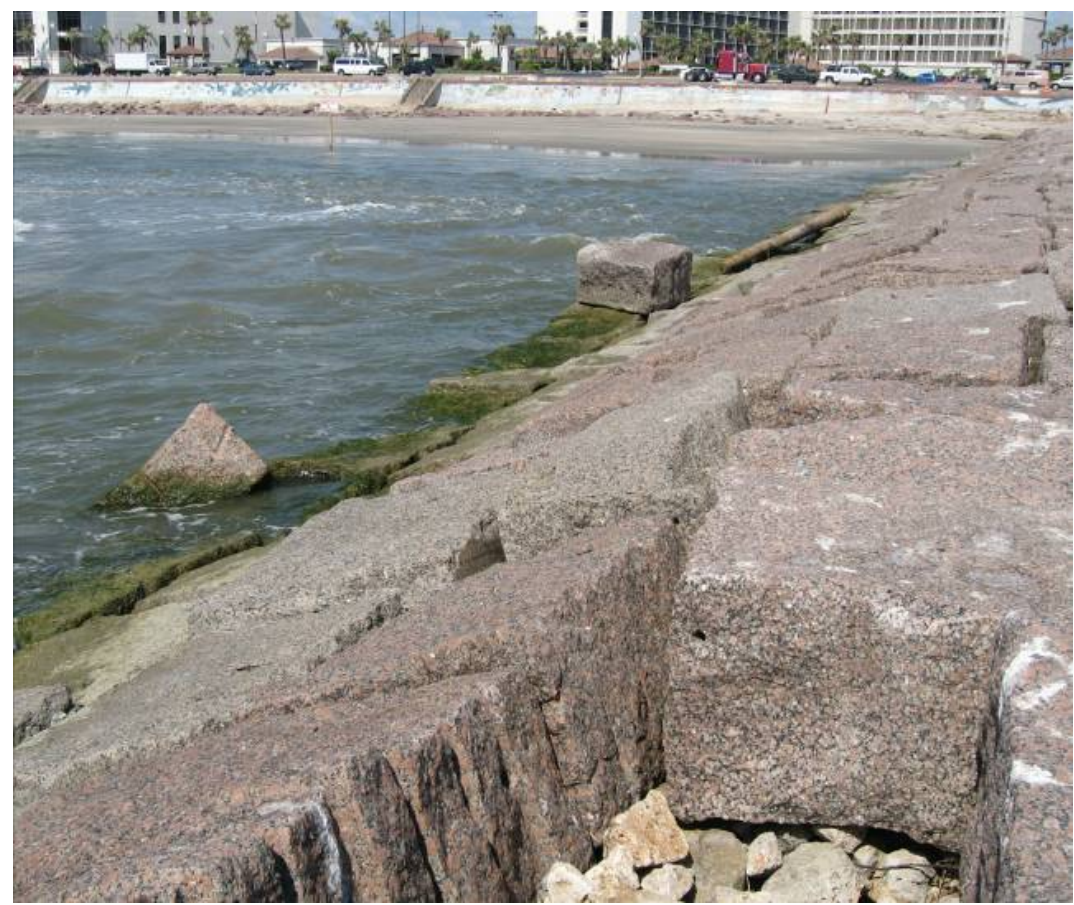

Figure 14 Displaced armor stone at 53rd Street groin

\section{Buildings}

Damages to the structures surveyed included wind, surge or wave damages. Some structures exhibited damages from all three forces. Post-storm damage surveys served to confirm expected performance in extreme conditions as well as to evaluate recent development trends and conditions unique to each type of storm forcing. Most of the buildings in the highest risk areas near the gulf and bays were wood-frame, single-family houses and are the focus of this section. Larger buildings were either more distant from the gulf or protected by the Galveston Seawall.

Wind. Peak wind speeds appeared to be below design levels in the areas inspected. Minor wind damage to buildings was widespread, but serious structural damage was rare with a few exceptions as shown in Figure 15. Damage to roof coverings, often one of the most damage-prone components, was common but not uniformly present, as observed in other recent high-wind hurricanes. Many flood damaged buildings appeared to be undamaged by the wind. Wind damage to the single-family houses along West Beach appeared to be much less severe than that observed following Hurricane Alicia in 1983 (Rogers et al. 1985). The likely differences are somewhat lower wind speeds across that specific shoreline; prior damage to the older, most wind-sensitive buildings; and post-Alicia improvements in general construction practice, building codes, and inspections.

Storm Surge. Evaluation of the storm surge elevations will require more detailed analysis, but observations support preliminary reports that most of the Gulf of Mexico shoreline from East Beach west to Surfside had flood elevations below the design requirements described in the most recent flood maps. The common construction practice of elevating houses on shallow piling foundations, with underhouse parking or storage in some cases, effectively provided freeboard above the required elevations. USGS storm surge gauge reports and observations of wave damage elevations for this study suggest that water levels exceeded floodmap levels for much of Bolivar Peninsula. Beyond the stillwater flood damage, the primary cause of severe structural damage was wave damage near the gulf and around the larger bays. 


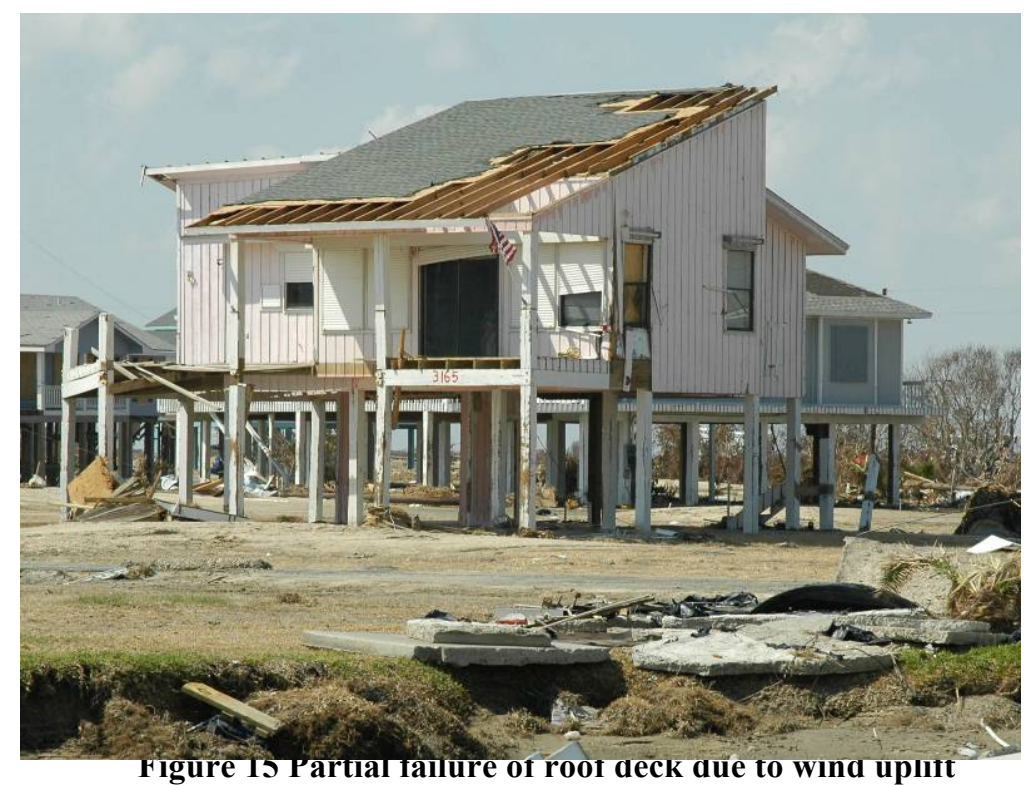

Waves. Storm surge and wave elevations caused increasing frequencies of structural damage along the gulf shoreline from the Galveston Bay jetties east along the Bolivar Peninsula to the end of the development near High Island. Most of the buildings were single-family houses. Once the wave elevations exceed an open piling foundation elevation, severe structural damage occurs quickly. The floor systems of most houses are highly susceptible to failure after only a few waves. Typical structural damages leave nothing but the pilings (Figure 16) or, with shallow piles, total removal of the building. A section of homes considered total losses due to wave damage extended several blocks wide along the east end of the peninsula as shown in Figure 17. The first two rows experienced erosion landward of a geotextile tube. More landward buildings were destroyed by waves. Surviving buildings, circled on the left side of the photos had higher floor elevations.

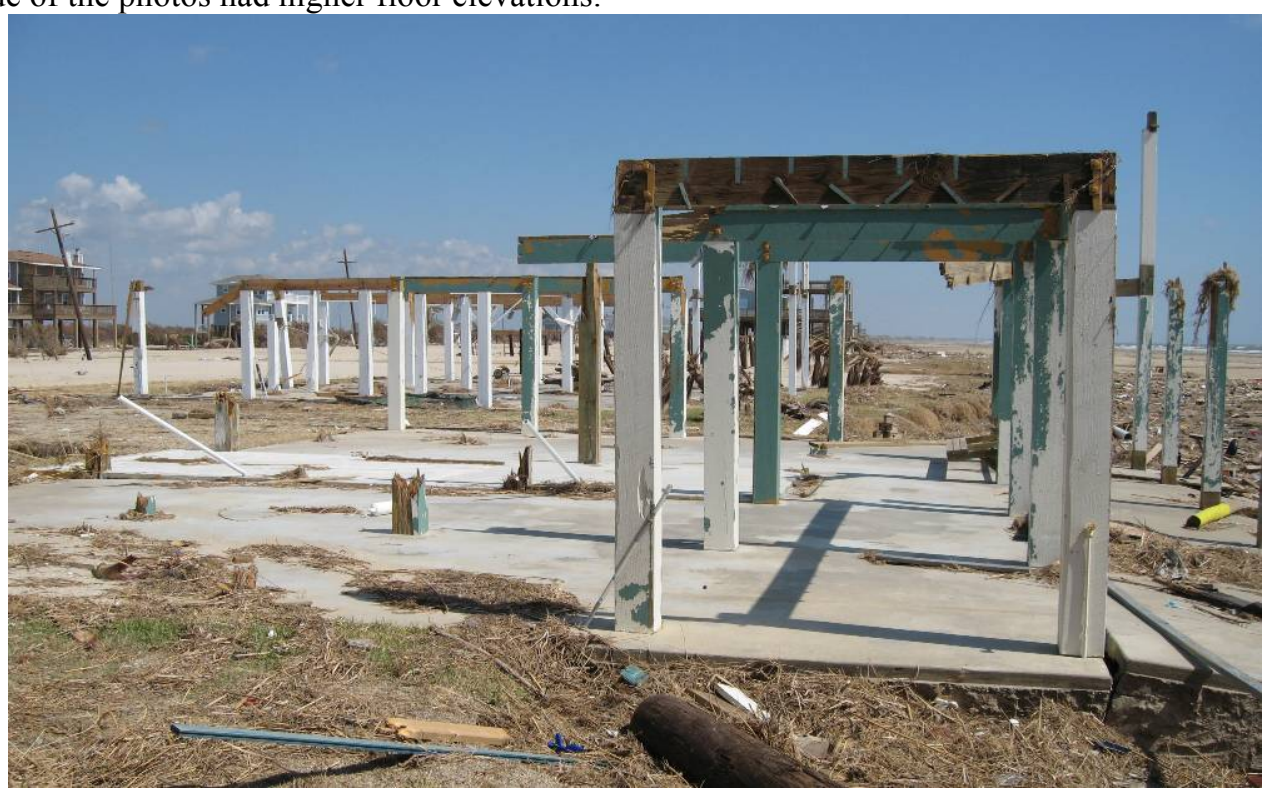

Figure 16 Structural failure due to wave uplift and lateral forcing

Farther landward, damage gradually reduced in severity, evidenced by decreasing levels of breakaway wall failures, which suggests a likely gradual drop in wave height. Farther west on Bolivar Peninsula around Gilchrist and Rollover Pass, losses of buildings across the peninsula approached 100 percent, and wave damage was apparent across the entire peninsula. The common characteristic of the surviving and partially remaining houses was an open, piling foundation with a higher floor elevation. The remaining pilings with no superstructure suggest that lower elevation houses disintegrated or were washed into the bay. Preliminary analysis of building wave damage elevations based on LIDAR ground 
elevations suggest that wave crests reached elevations of +5.5 to $+6.2 \mathrm{~m} \mathrm{NAVD}$ and 0.5 to $1.2 \mathrm{~m}$ above the minimum floor elevation requirements on the flood maps in effect at the time of the storm. Many houses constructed at the minimum elevation requirement were also destroyed in the storm.

Erosion Damage. As noted previously, the entire study area has low ground elevations and dunes with little to no elevation. Erosion damage to building foundations was observed from two causes: wave-induced retreat of the shoreline and localized scour as the storm surge moved over the flooded landform. The shoreline erosion affected the first row or two of buildings from West Beach to Surfside and along the Bolivar Peninsula. Localized scour was highly irregular across the developed areas. Scour frequently appeared to be deeper around foundations, likely due to increased turbulence and/or ground-disturbing activities associated with the original construction. Observed ground disturbances included auger installation of shallow piling foundations and the replacement of originally consolidated clays with unconsolidated material around the building footprints (Figure 18). Often the scour appeared random but was likely affected by local sediment variations in addition to buildings, roads, canals, and other surface structures (Figure 19). Not surprisingly, localized scour was more likely closer to the gulf or bay shorelines and was more widespread where the landforms were narrowest, as observed near Rollover Pass. The erosion patterns suggested both onshore and offshore flow on the Bolivar Peninsula. Figure 20 illustrates how the scour at slab foundations typically caused failure of the limited structural support provided by the slabs to the columns. Moreover, it can be seen how this erosion pattern grew to cover a large area including other foundations.

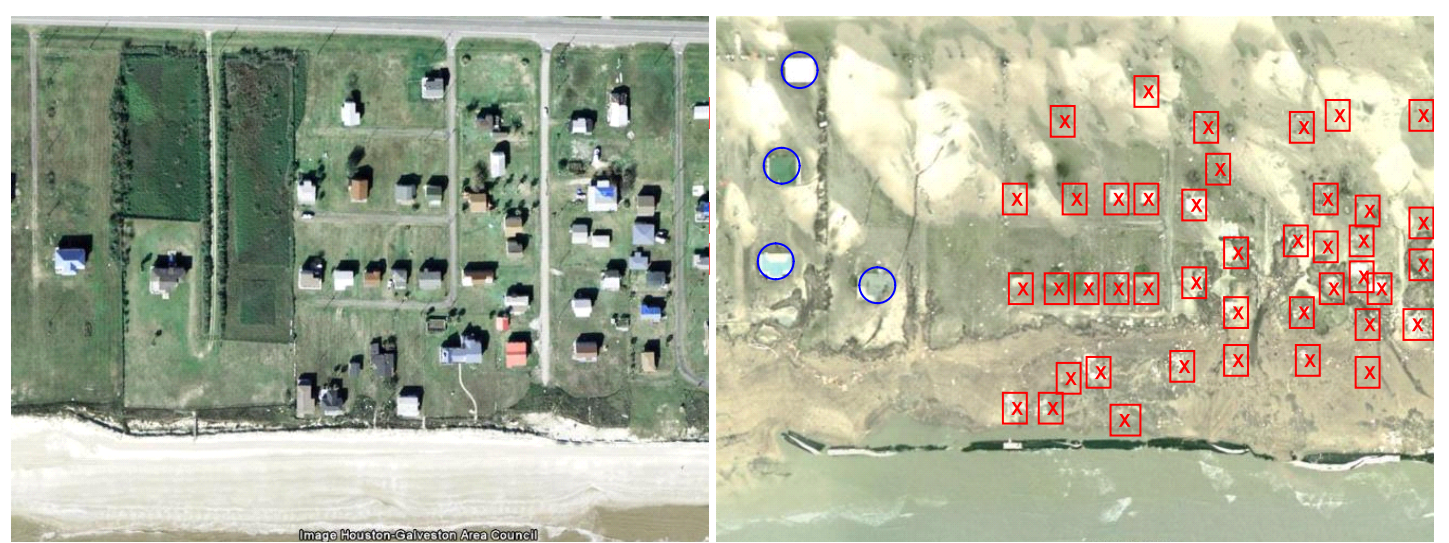

Figure 17 Building survivors and failures on the Bolivar Peninsula. Source: Houston Area Council and NOAA images

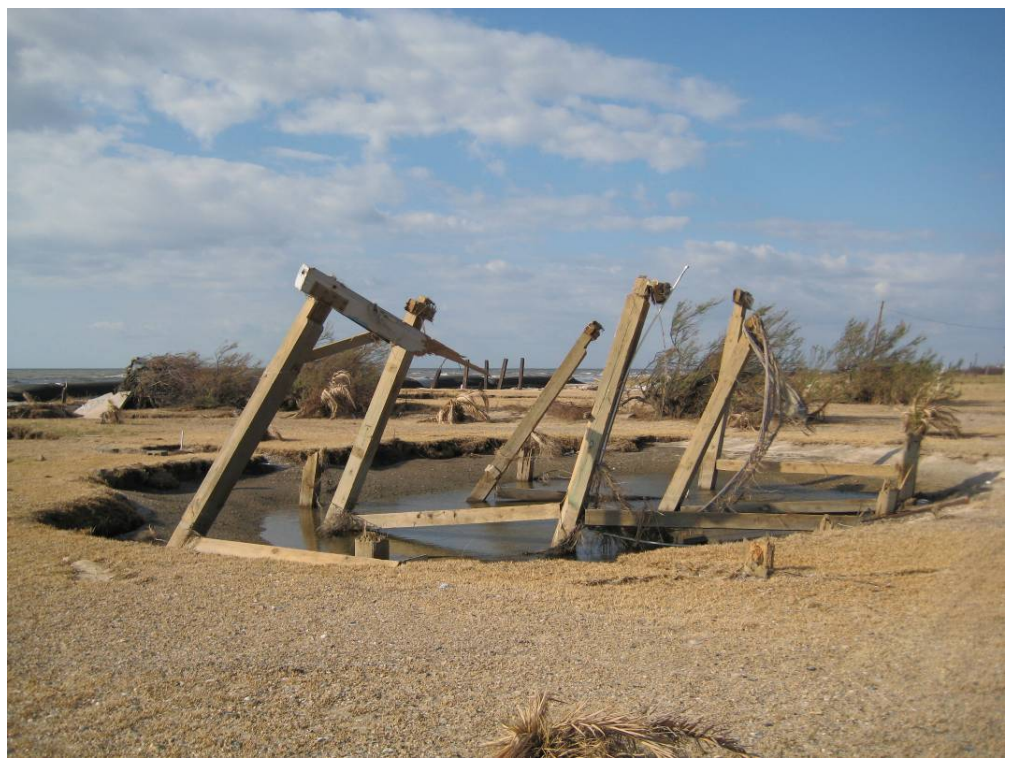

Figure 18 Localized scour engulfing the full footprint of the short pile foundation 


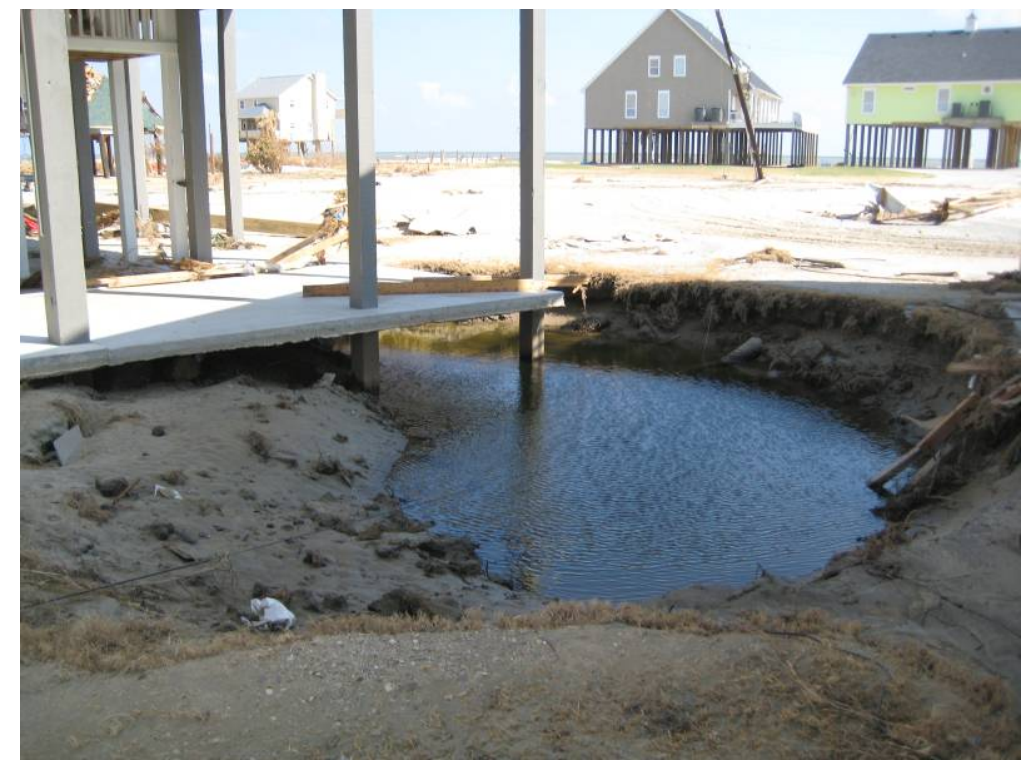

Figure 19 Local sour at the corner of the ground slab

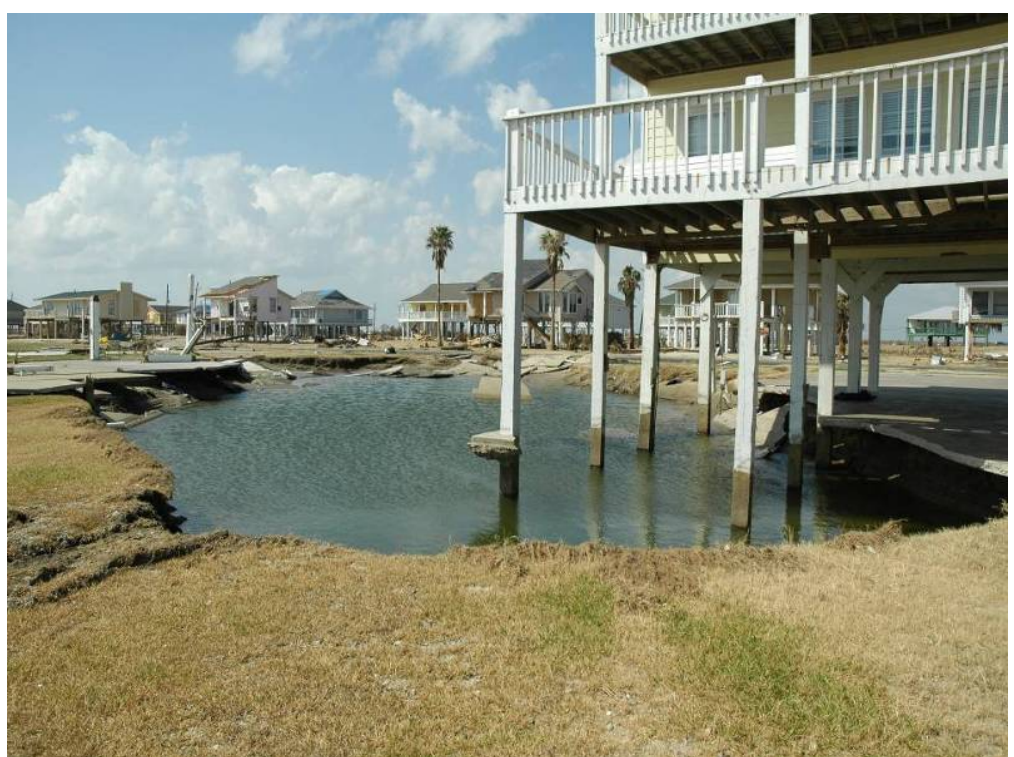

Figure 20 Illustration of growth of scour from slab foundation

\section{Marinas}

Damage to the area's marinas varied widely, with Galveston Boat Basin seemingly received modest infrastructural damage from the storm. Exposure to high water levels and waves in Galveston Bay was responsible for the differences in different marinas surrounding the bay. The floating dock, roof structure, and finger piers at Seabrook Shipyard appeared to work as designed, and its performance seemed to mitigate the level of damage that would otherwise have occurred.

However, it is clear that the improper securing or maintenance of boats to survive a storm contributes to facility damage. Boats that break free of their moorings (Figure 21) or that still have masts and sails in place when a storm arrives can cause tremendous damage; they can collide with docks, bulkheads, other boats, and even buildings. While it is likely that broken piles and detached cleats (as seen at Galveston Yacht Basin) also contributed to boats becoming loose during the storm, much damage can be mitigated by properly securing vessels and providing an appropriate amount of fenders for them. Additionally, slinging small powerboats out of the water does not provide sufficient protection for them during a storm. 


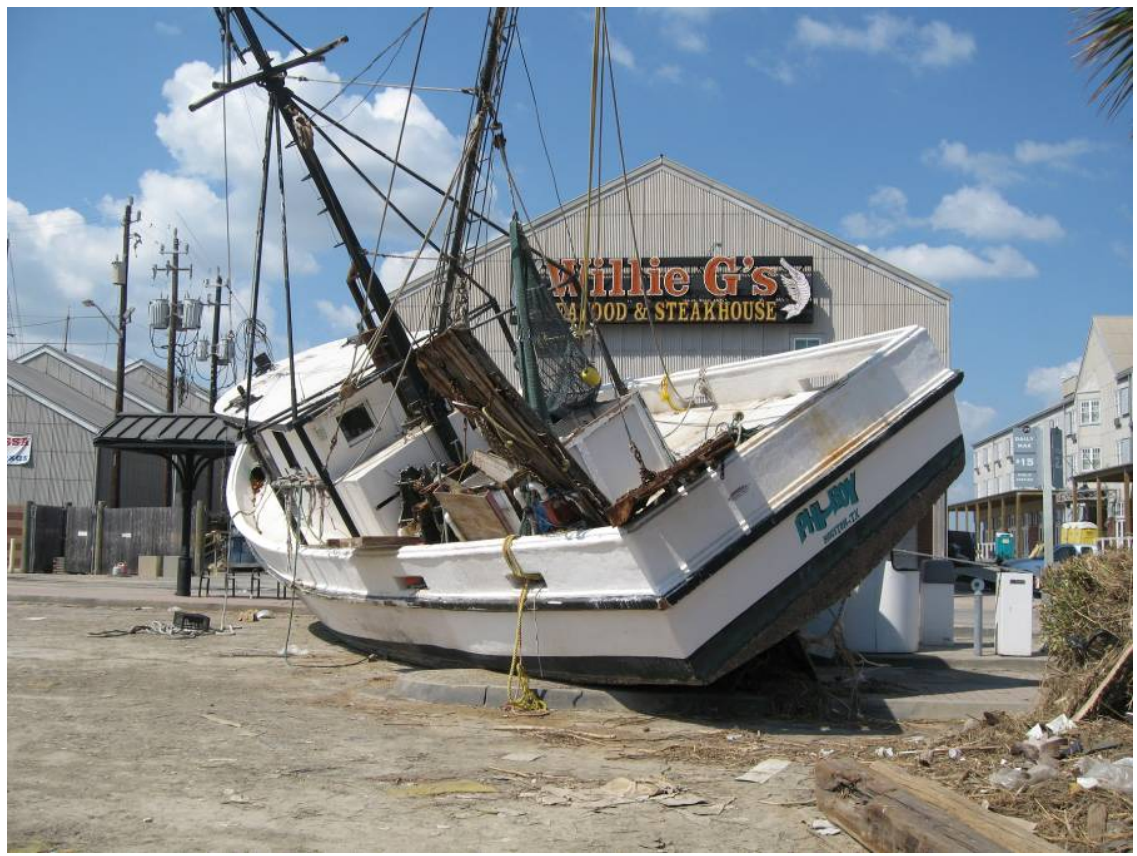

Figure 21 Boats breaking mooring lines during the storm can be a battering ram

\section{CONCLUSIONS}

Several lessons were learned from Hurricane Ike and many are the same as learned in previous storms. Some of lessons are:

- Erosion is an important determinant of coastal vulnerability.

- Storm-induced shoreline retreat and localized scour around structures can contribute to structural failure.

- The key components for successful storm-resistant coastal buildings include open, elevated foundations with adequate embedment.

- The safety factors beyond minimum standards to be considered are deeper piling embedment, and higher floor elevations.

- Hurricane Ike transported large volumes of sand from the beach to inland areas, forming extensive overwash fans 100 to $150 \mathrm{~m}$ inland of the shoreline. Finding debris lines further inland than the overwash fans suggests that the volume sand supply was a limiting factor to the extent of the overwash fans.

- The Galveston Seawall and the increased elevation landward of the seawall (grade raising) effectively protected the inland development from major water-related damage from the ocean side.

- The geotube installations had observable but limited benefits for the surge and waves from Hurricane Ike. This is likely due to the surge overtopping the tubes.

- There is need for comprehensive evaluation of regional vulnerability.

Some observations point to needed changes in housing requirements, including use of composite foundations. Some marinas showed little to no damage while others were significantly or totally destroyed. The major civil works, water and wastewater systems were placed inline quickly and efficiently except on Bolivar. Several lessons from previous natural disasters can be relearned from the observations made after Hurricane Ike. Hopefully, they will be carried forth into future design and management of coastal communities.

\section{ACKNOWLEDGMENTS}

The authors would like to especially acknowledge the Corps of Engineers for providing support for Dr. Donald Stauble, Dr. Jeffrey Waters and Eddie Wiggins. The Port and Airport Research Institute, Japan, provided support for Dr. Kojiro Suzuki. Dr. Garry Gregory assisted the team with his geotechnical experience and both Mandy Loeffler and Marie Horgan Garrett provided essential local knowledge. Of course without the funding of COPRI and the GeoInstitute of ASCE, this trip would not have been possible. 


\section{REFERENCES}

Berg, Robbie, 2009. "Tropical Cyclone Report: Hurricane Ike (AL092008) 1-14 September 2008, National Hurricane Center. 55 p. Available online: http://www.nhc.noaa.gov/2008atlan.shtml.

Bunpapong, M., R. O. Reid and R. E. Whittaker (1985) “An Investigation of Hurricane-Induced Forerunner Surge in the Gulf of Mexico", Technical Report CERC-85-5, Coastal Engineering Research Center, U. S. Army Waterways Experiment Station, Vicksburg, MS.

FEMA, 2000. Coastal Construction Manual: Principles and Practices of Planning, Siting, Designing, Constructing, and Maintaining Residential Buildings in Coastal Areas. FEMA 55, (3rd ed.).

Hansen, B., 2007. Weathering the Storm: the Galveston Seawall and Grade Raising. Civil Engineering, 77(4), 32-33.

Kennedy, A. (2010) "Innundation and Destruction on the Bolivar Peninsula During Hurricane Ike," Proceedings of International Conference on Coastal Engineering 2010, Shangahi.

Kraus, Nicholas C. and Lihwa Lin, 2009. "Hurricane Ike along the upper Texas Coast: an introduction," Shore and Beach, 77(2), 3-8.

Ravens, T. and K.I. Sitanggang, 2002. “Galveston Island: Texas' First Open Beach Nourishment Project, 1995-2001." Proceedings for 2002 National Conference on Beach Preservation Technology, pp. 189-198.

Rogers, Spencer M. Jr., Peter R. Sparks, and Katharine M. Sparks, 1985. "A Study of the Effectiveness of Building Legislation in Improving the Wind Resistance of Residential Construction." Proceeding from National Conference on Wind Engineering, Lubbock, TX. Wind Engineering Council. pp. 5A 27-34.

Rogers, Spencer M. Jr., and Sam Houston, 1997. "Hurricane Surge and Wave Conditions: Research Needs." Waves '97 Conference Proceedings. ASCE.

Spadoni, R.H., 1996. "Nourishment of the Beach in Galveston, Texas", Houston Geological Society Bulletin, April 1996. 